\title{
ANALISIS NILAI KARAKTERISTIK TOKOH UTAMA PADA NOVEL HAID PERTAMA KARYA ENNY M
}

\author{
Andi Adam \\ Program Studi PGSD, Universitas Muhammadiyah Makassar \\ andi.adam@unismuh.ac.id
}

\begin{abstract}
ABSTRAK
Penelitian ini bertujuan memperoleh pengetahuan tentang karakter tokoh utama dalam novel Haid Pertama karya Enny M. Penelitian ini adalah penelitian pustaka dan merupakan penelitian deskriptif kualitatif. Sumber datanya adalah novel Haid Pertama, merupakan hasil karangan atau imajinasi Enny M. yang berwujud menjadi kenyataan dalam bentuk karya yang utuh yaitu novel. Teknik yang digunakan adalah teknik observasi tidak langsung atau biasa dikenal dengan istilah observasi berstruktur. Hasil analisis data yang dihimpun, peneliti menentukan faktorfaktor edisi atau deskripsi tokoh utama sesuai dengan bukti atau petunjuk yang ditentukan. Jadi dapat dikatakan bahwa gambaran karakter tokoh utama dalam novel Haid Pertama yaitu Diena, adalah gambaran karakter seorang tokoh yang masih gadis belia segolongan SMP yamg masih kekanak-kanakkan, selalu mencari hiburan dirinya, sedikit kasar, rajin berusaha dan suka berpenampilan menarik atau tampil beda di hadapan teman-temannya.Sifat kekasaran yang dimiliki Diena merupakan akibat kegelisahan dari keterlambatan datang haidnya, karena ia merasa cemas dan gelisah kalau nantinya Diena akan menjadi wanita yang tidak normal atau mandul, serta merasa malu terhadap teman-temannya dan orang lain. Namun sifat kekasaran Diena tidak menjadi sebuah karakter remaja yang bersifat kepribadiannya. Karena setelah berumur 14 tahun, tepat hari ulang tahunnya Diena mendapatkan hadiah ulang tahun dari yang Kuasa dengan sebuah kado yang istimewa yang selama ini Diena dambakan, yaitu haid pertamanya.
\end{abstract}

Kata Kunci: Nilai, karakterisik, tokoh utama, novel Haid pertama

\section{ABSTRACT}

This research aims to gain knowledge about the main characters in the novel M. Haid First works Enny This research is a library and a qualitative descriptive study. The data source is a novel Haid First, is the result of a bouquet or imagination Enny M. tangible reality in the form of the whole work is novel. The technique used is the technique of indirect observation or commonly known as the observation structured. The results of the analysis of the data collected, researchers determine the factors edition or description of the main character in accordance with the evidence or the instructions specified. So we can say that the character description main character in the novel Haid First, the Diena, is the character description of a character who was still quite young class of junior yamg still childish, always searching for the entertainment itself, a bit rough, diligent effort and likes to look attractive or different in the presence of friends temannya. Sifat roughness owned Diena anxiety is the result of the delay came menstruating, because he felt anxious and nervous if later Diena will be a woman who is not normal or infertile, and was ashamed of his friends and others. But the nature of roughness Diena not become a teenage character that is his personality. Because after the age of 14 years, on his birthday Diena get a birthday gift from the Power of Attorney with a special gift that had been Diena dearer, the first period.

Keywords: Value, Characteristics, the main character, Haid Pertama novel

\section{PENDAHULUAN}

Karya sastra yang ada pada masyarakat, bukan sekedar atau mempunyai tujuan sematamata sebagai penghibur, sebaliknya juga bukanlah alat penyampaian wejangan-wejangan atau pendidikan semata. Sastra merupakan jalinan atau perpaduan antara kedua masalah tersebut. Dengan karyanya pengarang bermaksud menyampaikan gagasannya, pandangan hidup, tanggapannya terhadap sekitar kehidupan dengan cara yang menarik dan menyenangkan, atau dengan kata lain ujung-ujungnya adalah penghibur. Seorang pengarang bermaksud pula menyampaikan nilai-nilai yang menurut keyakinannya bermanfaat bagi penikmat karyanya. Seorang pengarang juga bukan hanyalah sekedar memindahkan apa yang disaksikan dalam kehidupannya semata, melainkan ia mempunyai tugas yang lebih jauh yaitu menafsirkan dan memaknai kehidupan yang disaksikan dan dirasakan orang lain ke dalam karyanya. Karena itu fungsi sastra bukanlah semata-mata untuk berusaha memberikan hiburan kepada penikmatnya melainkan juga pengarang 
berusaha memberikan nilai-nilai yang anggun dan agung yang sering terlepas dari pengamatan sehari-hari.

Secara eksistensi sastra adalah sesuatu yang konkret dalam dirinya, tetapi sebagai fenomena, sastra adalah cermin yang mendukung proses kehidupan dan kemanusiaan. Kenyataan itu sebenarnya telah terpatri di dalam fungsi sastra itu sendiri karena di samping fungsinya sebagai hiburan yang bermanfaat dan menyenangkan, sastra pula berfungsi sebagai menyingkap rahasia terhadap manusia, memberikan makna terhadap eksistensi manusia, dan membuka jalan kepada kebenaran.

Dari permasalahan yang diungkapkan di atas, sastra dapat dipahami apabila dikaji dan diteliti secara cermat salah satu cara memahami kandungan yang terdapat dalam sastra adalah memahami dasar pengkajian sastra yaitu terdapat dua unsur, seperti unsur intrinsik dan ekstrinsik.

Unsur intrinsik adalah unsur atau aspekaspek membangun karya sastra yang berbeda di dalam lingkungan sastra sendiri, sedangkan unsur ekstrinsik adalah unsur yang memberikan dukungan demi tetap eksis atau penyempurnaan dan memperlancar jalannya cerita.

Salah satu dari unsur intrinsik yang memberikan kemudahan bagi penikmat untuk dapat memahami karya sastra adalah dari segi pelaku cerita. Seluruh pengalaman yang dituturkan dalam cerita diikuti berdasarkan tingkah laku dan pengalaman serta yang dijalani pelaku dari awal cerita hingga akhir cerita, disebut karakterisasi atau penokohan.

Untuk memahami karakteristik atau penokohan dalam karya sastra dengan membaca dan mengikuti penceritaan hingga akhir ceritanya. Selain dari jalan tersebut diperlukan pula pemahaman psikologi .

"Manusia banyak dikuasai oleh alam batinnya sendiri, sehingga manusia selalu berada dalam peperangan dengan dirinya. Resah dan tertekan sewaktu merasakan ketidak seimbangan dalam kehidupannya bahkan perlu ada yang sebaliknya tokoh dalam menghadapi batinnya justru menghadapinya dengan tenang" (Jassin dalam Tarigan, 1985: 116).

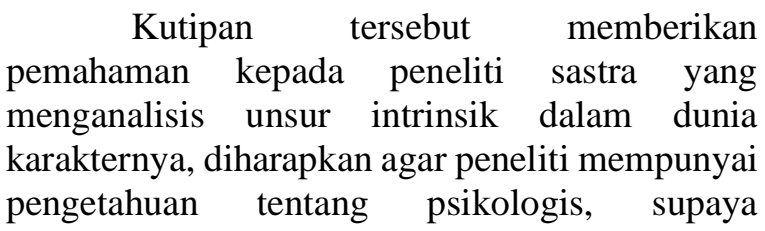

penganalisaan karakter tokoh dalam sastra tidak terlalu menjadi beban pikiran dalam mencapai yang diharapkan. Demi tercapainya hasil penelitian yang maksimal dan menarik dalam novel Haid Pertama adalah karakter tokoh utama.

Dilihat dari judul novel, maka penulis menaruh rasa tertarik untuk mengkaji atau menganalisis karakter tokoh utama dalam novel tersebut sebagai suatu masalah, karena pengarang menceritakan permasalahan yang dianggap sangat bertentangan atau bersifat lucu didengar, dan juga pengarang mengetengahkan tokoh dengan menciptakan latar dan waktu yang berbeda.

Pengarang dalam novel Haid Pertama mengungkapkan pandangannya tentang cinta, kesedihan, kekecewaan, kebahagiaan dan ketegasan melalui tingkah laku tokoh-tokoh yang diungkapkan dengan teliti serta gaya bahasa yang lancar dan patut diagungkan, sehingga peneliti merasa tertarik mengkaji dan menganalisis novel tersebut.

\section{TELAAH PUSTAKA}

Dari zaman ke zaman hakikat sastra itu tetap otonom, karena karya sastra memiliki dunia tersendiri. Sastra merupakan perpaduan dari berbagai dunia dan unsur kehidupan. Karya sastra adalah kehidupan yang diwarnai permainan atau imajinasi sastrawan. Kehidupan di dalam karya sastrawan adalah kehidupan yang telah diwarnai dengan sikap pengarangnya, latar belakang pendidikan dan sebagainya. Kebenaran yang terkandung dalam karya sastra adalah kebenaran yang berbentuk keyakinan atau kebenaran indrawi. Keyakinan tersebutlah yang dapat disaksikan oleh masyarakat penikmat sastra dalam kehidupannya sehari-hari.

Dilihat dari nama dan sebutan, kata novel selalu diidentikkan dengan sebuah cerita yang menceritakan tentang perjalan hidup tokoh-tokoh dalam ceritanya.

Tetapi kalau dibuktikan dengan pemahaman dan penjelasan yang terkandung dalam Kamus Besar Bahasa Indonesia (KBBI) bahwa novel adalah bentuk karangan yang lebih pendek dari pada roman, tetapi lebih panjang dari cerpen. Sifat dari novel lebih menceritakan sebagian kehidupan dari tokoh, yaitu suatu kehidupan yang luar biasa dari seluruh hidupnya yang menimbulkan konflik yang menjurus pada perubahan nasib sang tokoh (KBBI, 2005: 683).

Bila dilihat dan dicermati, maka benarlah anggapan bahwa novel itu mengandung cerita yang menceritakan sebagian kehidupan seorang 
tokoh yang dihadapkan dengan sebuah konflik yang menjurus pada perubahan nasib tokoh tersebut.

Dengan demikian dapat disimpulkan bahwa novel hanya menceritakan salah satu segi kehidupan sang tokoh yang benar-benar istimewa, kemudian mengalami perubahan nasib.

Pengertian novel juga dapat dijumpai dalam kamus istilah sastra, sebagai berikut:

Novel adalah proses rekaan yang panjang yang menyuguhkan tokoh-tokoh dan menampilkan peristiwa dan latar secara tersusun (Sadjiman, 1990: 55).

Kemudian menurut Nurgiantoro menafsirkan tentang novel adalah sebuah karya fiksi sebuah dunia, dunia yang berisi model kehidupan yang diidentikkan, dunia imajiner yang dibangun melalui unsur intriksinya, seperti peristiwa, plot, tokoh, penokohan latar, sudut pandang, dan lain-lain yang semua itu bersifat imajiner (Nurgiantoro, 1998: 4).

Novel adalah suatu karangan prosa yang bersifat cerita yang menceritakan suatu kejadian yang luar biasa dari kehidupan orang-orang (tokoh cerita), dari kejadian in terlahir suatu konflik, suatu kejadian yang mengalihkan unsur nasib mereka (Jassin, 1984: 49).

Dari beberapa pengertian yang dikemukakan oleh para ahli tersebut, maka dapat disimpulkan lewat pendapat Tarigan yang mengatakan bahwa novel adalah sebuah ekspolari atau suatu lukisan kronik penghidupan, perenungan, dan melukiskan dalam bentuk tertentu, pengaruh ikatan, hasil kehancuran atau tercapai gerak-gerik manusia (Tarigan, 1998: 10).

Sebagaimana yang telah dikemukakan dalam definisi novel, bahwa di dalam penjelasan tentang novel. Namun, pada hakikatnya novel dibangun dari dua unsur, yaitu.

1) Unsur intrinsik yaitu unsur yang membentuk dan membangun novel dari aspek-aspek yang ada di dalamnya, yang termasuk perwatakan, tema, karakter, alur/plot, pusat pengisihan, latar dan gaya bahasa.

2) Unsur ekstrinsik yaitu: unsur yang membangun novel yang berada di luar cerita, misalnya: faktor sosial, ekonomi, kebudayaan, politik, religius, dan tata nilai yang dianut masyarakat.

Penjelasan psikologis, Murphi dalam Wirawan (1992: 4) mengemukakan bahwa psikologi adalah ilmu yang mempelajari respon yang diberikan oleh si makhluk hidup terhadap lingkungan. Dengan kata lain, psikologi adalah ilmu pengetahuan yang mempelajari tingkah laku manusia.

Jadi, unsur psikologis sangat berpengaruh terhadap karakter karena karakter tak akan pernah bisa ditemukan dalam karya sastra apabila tidak memahami respon yang diberikan makhluk hidup terhadap lingkungannya.

Dalam pengkajian sastra diperlukan pendekatan psikologi. Di antara kritikan-kritikan sastra merintis dan mengajurkan pendekatan psikologis adalah I.A Richards yang mencoba menghubungkan kritik sastra dengan uraian psikologis semantik (Hardjana, 1981: 36).

Timbal balik dari pemahaman psikologis tersebut, maka yang menjadi titik perhatian adalah karakter, karena karakter adalah bagian dari ilmu kejiwaan atau psikologi itu sendiri.

Karakter dapat pula disebut dengan watak, tabiat, sifat, corak pribadi. Secara sederhana karakter adalah kondisi jiwa manusia yang diakibatkan oleh faktor dari dalam maupun dari luar yang membedakan dari orang lain (Muhsin, M. Arief. 2016). Secara khas baik yang dapat diubah maupun yang tepat dalam perkembangan kehidupan yang ditampakkan dalam tingkah laku.

Watak adalah keseluruhan (totalitas) kemungkinan-kemungkinan bereaksi secara emosional; (seseorang yang terbentuk selama hidupnya oleh unsur-unsur dari dalam (dasar, keturunan, faktor-faktor endogen) dan unsurunsur dari luar (pendidikan dan pengamalan, faktor-faktor eksogen) (Muhsin, M. Arief., 2016)

Walaupun istilah kepribadian dan watak sering dipergunakan secara bertukar-tukar, namun Allport menunjukkan bahwa biasanya watak menunjukan arti normatif, dia menyatakan bahwa character in personality evaluated (Allport dalam Suryabrata, 1990: 28).

Menurut Poedjawijatna tentang karakter atau watak adalah sebagai berikut: watak itu dapat dipengaruhi dan dididik, tetapi pendidikan watak itu tetap merupakan pendidikan yang sangat individual dan tergantung pada kehendak bebas dari orang yang dididiknya (dalam Purwanto, 1990: 144-145).

Di dalam buku yang sama, Kerehensteiner mengemukakan bahwa watak adalah keadaan jiwa yang tetap, tempat semua perbuatan ditetapkan. Atau ditentukan oleh prinsip-prinsip yang ada dalam alam kejiwaan (dalam Purwanto, 1990: 145-146).

Dari definisi yang diungkapkan oleh para ahli tersebut, bahwa karakter itu sangat berkaitan 
erat dengan unsur psikologi. Di dalam karakter itu sendiri dapat pula dikatakan sebagai watak. Watak yang terbentuk dalam diri manusia akibat dari ketergantungan individu dengan dunia pendidikan.

\section{METODE PENELITIAN}

\section{Variabel}

Variabel penelitian yang digunakan dalam penelitian ini adalah penulisan karakter tokoh utama dalam novel Haid Pertama karya Enny M. Sub variabelnya adalah sikap, reaksi, pelaku terhadap peristiwa tertentu, melukiskan kebiasaan atau keadaan lingkungannya.

\section{Desain Penelitian}

Desain penelitian pada dasarnya merupakan strategi yang dapat mengatur setting penelitian dan untuk membuat kerangka acuan dalam melaksanakan penelitian. Sebagai langkah awal dalam melaksanakan penelitian atau merumuskan suatu penelitian. Selanjutnya mengadakan studi kepustakaan atau studi literatur, kemudian menyelidiki variabel dan memberi definisi operasional variabel penelitian, metode yang digunakan dalam penelitian ini adalah metode deskriptif kualitatif yaitu mengumpulkan, mengubah menganalisis, dan menyajikan data secara objektif. Hal ini sejalan dengan pendapat yang dikemukakan oleh Hasan (1990: 21), bahwa hal tersebut merupakan ciri dari jenis penelitian kualitatif, sebab penelitian kualitatif tidak bermaksud mencari data untuk mendukung atau menolak hipotesis yang diajukan untuk mendukung atau menolak hipotesis yang diajukan penelitian di mulai.

Metode deskriptif merupakan suatu prosedur dalam pemecahan masalah yang diselidiki dengan menggambarkan atau mendeskripsikan keadaan objek penelitian berdasarkan fakta yang ada sebagaimana adanya. Kegiatan yang terakhir yakni laporan hasil penelitian dan menarik kesimpulan.

\section{HASIL DAN PEMBAHASAN}

Berdasarkan pengamatan terhadap novel "Haid Pertama" karya Enny M. dapat diketahui nilai karakter yaitu karakter tokoh. Namun yang menjadi titik atau inti permasalahan di dalam penelitian ini adalah yang berkaitan dengan karakter tokoh utama saja. Maka untuk menggambarkan karakter tokoh utama yang ada dalam novel Haid Pertama Karya Enny M. dapat dianalisis lebih mendalam berdasarkan pemahaman karakter dengan disertai kutipankutipan yang menjadi bukti konkret.

Penganalisisan sebuah cerita atau novel yang berkaitan dengan karakter, pengarang menempuh dengan memahami jalan secara langsung dan secara tidak langsung. Dari kedua jalan tersebutlah yang menjadi fenomena peneliti untuk mengetahui karakter tokoh utama yang ada dalam novel tersebut. Adapun penjelasan dari dua jalan yang dimaksud, sebagai berikut:

\section{Secara Langsuang}

Seperti yang dikatakan Junaedin bahwa secara langsung karena pengarang atau pencerita mendeskripsikan sifat atau karakter pelakunya secara langsung. (1992: 82). Bila dilihat atau dicerna lebih jauh yang dikatakan oleh Junaedin tersebut, maka yang muncul adalah persoalan riil adanya penceritaan tersebut. Akan tetapi permasalahan nyata dan riilnya sebuah karya, masih jauh dari kenyataan yang hakiki. Karena terbentuknya sebuah karya sastra atau novel adalah semata-mata hasil imajinasi para pengarangnya.

Mungkin bisa diberikan sebuah tanggapan dari pendapat itu, bahwa melihat karakter secara langsung adalah suatu imajinasi pengarang yang memberikan karakter tertentu kepada tokoh utamanya secara langsung. Dalam arti, pemberian karakter terhadap tokoh utama memiliki perbedaan-perbedaan yang istimewa dibandingkan dengan tokoh-tokoh pembantu lainnya.

Oleh karena itu, di dalam novel Haid Pertama yang menjadi tokoh utamanya adalah Diena. Memiliki karakter yang digambarkan secara langsung oleh pengarang sebagai berikut:

"Mau ngapain sih, lo Min? setan, lo, bikin jantung gue mau copot aja, gerutu Diena untuk menetralisirkan perasaannya (Haid Pertama: 8).

Gambaran karakter yang tampak pada kutipan di atas, menunjukkan karakter anak-anak yang sedikit keras terhadap suatu masalah yang tiba-tiba menimpa dirinya. Namun kalau dilihat kejadian yang sebenarnya sehingga muncul bahasa pada kutipan di atas, bahwa si pembantunya membuka pintu kamarnya Diena secara tiba-tiba, kebetulan Diena sedang membaca sebuah majalah akhirnya dia kaget kehadiran pembantunya itu. Maka keluarlah bahasa kasar secara sadar atau tidak sadar.

Bahasa-bahasa yang menggambarkan karakter secara langsung, juga terdapat pada 
kutipan berikut dan hampir sama dengan bahasa kutipan di atas.

"Diena melotot mendapati Minah sibuk memberesi isi kamarnya, lebih melotot pada majalah yang tadi ia tindikan bantal" ........ keluaaaaar!" jeritnya histeris seraya berlari menyembunyikan majalah itu ke laci. Maki! Seru Diena dalam hati".

\section{Keluar!"}

Dasar tolol udik!" makinya tersedu" (Haid Pertama: 14).

kalimat $\begin{gathered}\text { Berdasarkan } \\ \text { kutipan }\end{gathered}$ tersebut $\begin{gathered}\text { bahasa dan } \\ \text { memberikan }\end{gathered}$
menunjukkan karakter yang secara langsungnya karakter yang sungguh keras, namun bisa dibaca bahwa permasalahan Diena dengan pembantunya bukan berarti Diena membencinya atau bersifat keras terhadap pemabantunya. Permasalahannya adalah ada sesuatu majalah yang tidak bisa diketahui oleh pembantu dan seisi rumahnya. Majalah-majalah yang Diena selalu baca adalah majalah kakaknya Mbak Dewi yang masalah khusus wanita.

"Majalah milik kakaknya, Mbak Dewi, yang kuliah di Trisakti, semester terakhir. Majalah khusus wanita.

Dan ini menarik, sebagai contoh yang ia simak itu, SEPULUH RAHASIA LAKI-LAKI" (Haid Pertama: 14 - 15).

Diena merasa tersinggung, ketika pembantunya mendapati majalah yang ada di tempat tidurnya adalah majalah kakaknya, yang membahas masalah laki-laki.

Dari kedua potong kutipan yang digambarkan di atas menunjukkan bahwa Diena sebagai tokoh utama yang berumur 14 tahun, mempunyai karakter yang masih kekanakkanakkan, karena sifat emosional golongan anakanak itu masih diwarnai akibat pergaulannya.

Namun sebagai gambaran awal terhadap karakter tokoh utama yang sedikit keras, kemungkinan pada analisis secara tidak langsung yang membahas lebih mendalam tentang isi novel tersebut, akan tampak suatu karakter yang didapati suatu perubahan, karena pengamatan secara langsung hanya sebagai dasar awal pengembangan sebuah cerita atau novel.

Oleh karena itu, pengarang mendeskripsikan lebih lanjut karakter tokoh utamanya dengan menggunakan cara yang lain adalah cara tidak langsung.

Pengamatan secara langsung adalah suatu gambaran yang mendasari pemberian karakter awal terhadap tokoh, guna pengembangan karakter yang jelas dalam penceritaan. Jadi, gambaran secara langsung hanya sebagai modal pengembangan karakter tokoh penceritaan yang akan berlangsung.

Berkaitan dengan permasalahan tersebut, maka dapat digambarkan bahwa pengarang tidak terlalu memberikan gambaran karakter tokohnya secara langsung. Sehingga penulis menitikberatkan pada penulisan ini dalam penggambaran karakter secara tidak langsung.

\section{Secara Tidak Langsung}

Penggambaran karakter secara tidak langsung adalah penggambaran karakter yang utuh dalam sebuah cerita atau novel. Dikatakan utuh, karena bentuk penggambaran karakter dalam suatu cerita hanya terdapat dalam hasil imajinasi. Maka tepatlah penganalisisan sebuah cerita atau novel ditempuh dengan melihat dan mengamati penggambaran karakter secara tidak langsung.

Jadi, demi terbentuknya gambaran karakter tokoh dalam penganalisisan ini, sangatlah tepat digunakan penggambaran secara tidak langsung. Disisi lain dapat menunjang bagi pengarang untuk melanjutkan hasil karyanya yang lebih transparan dan bernilai bagi penggemar karya sastra yang terkhususnya pada novel.

Untuk mempermudah memahami karakter tokoh utama yaitu Diena melalui gambaran secara tidak langsung, penulis dapat menempuh dengan jalan, seperti: mengamati sikap (bentuk tubuh dan perbincangan pelaku), reaksi pelaku, dan kebiasaan atau kegemarannya.

Langkah-langkah tersebut dapat dijelaskan disertai kutipan novel lebih lanjut sebagai berikut:

\section{a. Sikap}

- Penggambaran karakter melaui gambaran bentuk tubuh pelaku utama

Salah satu faktor dalam penggambaran karakter seseorang melalui sikap adalah pendektesian melalui bentuk tubuhnya. Karakter akan sedikit nampak dalam lekukan dan bentuk tubuh. Dari faktor ini sedikit atau banyaknya memahami karakter terhadap sesama manusia.

Lain halnya menggambarkan karakter sesama manusia melalui penceritaan atau novel. Penggambaran karakter melalui penceritaan semata-mata mendapatkan gambaran yang 
berupa fiktif-fiktif saja atau bentuk kebenaranya belum tentu pasti. Letak kebenaran karakter yang digambarkan pada penceritaan merupakan salah satu usaha untuk memahami karakter manusia pada kehidupan nyata. Namun sebagai penggambaran atau pemberian karakter terhadap tokoh Diena dalam novel Haid Pertama dilihat dari bentuk tubuh dalam penceritaanya sebagai berikut:

"Diena terus mengamati bentuk tubuhnya lama. Baru perlahan diangkat kaosnya, menarik single putih polos yang ia kenakan. Terakhir, dibukanya tali miniset yang membungkus buah dadanya. Buah dadanya tidak mungilmungil amat, mencuat putih sesuai warna kulitnya dengan puting kemerahan. Tapi, tetap saja tidak mampu memberi kesan sexi karena dengan tinggi $155 \mathrm{~cm}$, berat $40 \mathrm{~kg}$, dia lebih terlihat kurus. Apa lagi pantatnya rata, apa ini karena ia belum haid" (Haid Pertama: 27).

Dilihat dari kutipan di atas, terlihat sebuah permasalahan yang dihadapi Diena berkaitan dengan keterlambatan datang haidnya. Keadaan tubuh yang memperlihatkan bagianbagian yang intimnya masih menyamai warna kulitnya, bahkan tinggi dan berat badanya yang tidak seimbang karena badanya kurus, memberikan gambaran bahwa Diena masih tergolong mempunyai karakter yang masih kekanak-kanakkan dan sedikit cengeng.

Karakter Diena yang sedikit cengeng tersebut hampir semua anak-anak segolongan dia mengalaminya. Apalagi ditambah permasalahan haidnya yang belum kunjung datang juga. Jadi dari bentuk tubuh yang digambarkan pada kutipan tersebut merupakan salah satu karakter yang diwarnai penuh dengan kegelisahan terhadap terlambat datang haidnya.

Sedangkan dalam kutipan berikutnya mengungkapkan bahwa:

"Kau masih dalam masa pertumbuhan, tubuhmu masih bisa berkembang, walau barangkali nanti tidak semontok Cecilia karena setiap orang kan, punya tipe tubuh yang berbeda-beda" (Haid Pertama: 68).

Kutipan di atas memberikan penegasan dari kecemasan yang dialami oleh Diena akan keterlambatan datang haidnya.
Kalau dilihat lebih jauh kandungan dari kutipan tersebut, menandakan bahwa Diena masih mengalami masa pertumbuhan, walau tidak saperti masa pertumbuhan yang dialami oleh teman-temanya.

Rasa dan sifat was-was yang dialami oleh Diena selalu tergambar pada bentuk tubuhnya, ini karena masih dalam proses atau masa pertumbuhannya, sehingga pada umurnya yang masih muda itu belum bisa dikatakan gadis sempurna. Adapun kutipannya sebagai berikut:

"Coba dadanya lebih membusung, pasti gaun yang dikenakan akan lebih pas, sexi. Mungkin nanti setelah ia SMU pelan-pelan tubunya akan tumbuh sebagai cewek sempurna, saat ini kan ia masih masa pertumbuhan, pikirnya" (Haid Pertama: 93).

Walau keadaan tubuhnya yang kurus dan bentukan dadanya masih rata, Diena tetap berusaha semaksimal mungkin untuk tetap kelihatan seksi dalam penampilan atau selalu menampakkan tubuhnya sebagaimana yang dilakukan teman-temannya yang sudah mengalami haid.

Diena memang berkarakter tidak mau kalah dalam penampilan di hadapan temantemanya, dan selalu merahasiakan apa yang dialaminya yaitu gelisah akan terlambat datang haidnya.

Sifat kemanjaan dan kecengengan Diena juga dapat dilihat pada tubuhnya dikala berhadapan dengan teman laki-lakinya. Contohnya pada kutipan dibawah ini:

"Kurus dan sedikit berjerawat, juga bau keringat. Seumur-umur ditaksir cowok juga baru sama Toro, itu pun barangkali karena saat jumpa pertama ia dandan habis. Walau kata semua orang ia manis, tapi jauh dari kata 'cantik' (Haid Pertama: 83).

Badan atau tubuh yang kurus serta berjerawatr, adalah suatu keadaan yang alamiah, bukan penggambaran karakter. Namun Diena berdandan habis sehingga kelihatan manis walaupun tidak terlalu cantik. Ini merupakan suatu karakter yang dapat menyembunyikan kekurangan pada diri sendiri. Dari hal tersebut dapatlah dibuktikan bahwa Diena selain bersifat cengeng juga mempunyai sifat pintar menyembunyikan masalah yang tidak perlu diketahui orang lain. 
Jadi, dilihat dari semua permasalahan bentuk tubuh Diena dikaitkan dengan tipe karakter, Diena memiliki karakter suka berpenampilan menarik untuk menutupi kekurangan yang dialami dirinya.

Badannya kurus, dan bentukkan dadanya yang belum nampak, merupakan unsurunsur biologi yang berkaitan dengan hormon. Namun dapat digambarkan keadaan tubuh seperti itu cenderung berkarakter cengeng, manja dan ingin selalu tampil beda.

- Penggambaran karakter melalui
perbincangan pelaku
Faktor kedua dalam gambaran karakter terhadap sikap adalah gambaran karakter melalui faktor perbincangan pelaku. Untuk menggambarkan karakter pada faktor ini, pengarang memberikan gambaran karakter kepada pelaku utama dari hasil perbincanganperbincangan dengan pelaku lainnya. Maksudnya dari perbincangannya tersebut, dengan mudah memahami walaupun tidak sepenuhnya dipahami karakter yang sesungguhnya, tetapi sebagai gambaran-gambaran awal pengidentikkan karakter terhadap pelaku utama. Karena karakter yang sesungguhnya dapat diketahui apabila sudah melalui dari semua unsur-unsur penggambaran karakter sebagai usaha penganalisisan terhadap karakter pelaku utama nantinya.

Oleh karena itu, salah satu usaha menciptakan dan menggambarkan karakter tokoh utama sebagai faktor kedua adalah menyimak dan mengamati cara dan tuturan bahasa dalam perbincangannya dengan pelaku lain.

berikut:

Adapun contoh kutipannya sebagai

"Heh, dengar gak lo! Ngapain masukmasuk kamar gue? Lain kali ketuk dulu, tahu!" kali ini Diena bangkit dari tempat tidur, bertolak pinggang membuat Minah ketakutan, juga kebingungan.

"A-nu, Non....ada telepon dari Cecilia, teman sekolah Non yang..."

"Kenapa gak bilang dari tadi”(Haid Pertama: 9).

Dilihat dari bahasa yang dituturkan oleh Diena dalam perbincangannya dengan pembantu pada kutipan di atas, tampak sebuah karakter yang agak keras. Mungkin Diena merasa dikagetin dan merasa sebagai tuan rumah itu, maka Diena tanpa pikir matang-matang membentak pembantunya yang langsung buka pintu kamarnya.
Kalau dihat dan disimak perbincangan Diena dengan pembantunya (Minah), sepertinya tidak terlalu membahagiakan hati, karena terlalu kasar, atau mungkin begitulah kenyataan yang terjadi antara tuan rumah yang masih muda dengan pembantu rumah tangga. Karena dalam cerita novel tersebut, perbincangan Diena dengan pembantunya tidak pernah ditemukan bahasabahasa berwibawa.

"Minaaah!" teriak Diena kemudian.

Minah yang dipanggil tergopoh-gopoh datang ke kamar Diena.

"Lo lagi ngapain?"

"Nyante, Non. Pekerjaan MInah sudah beres semua kok." minyak ini!"

"Kalo gitu tolong pijitin gue pake

"Tutup pintunya, terus kunci... lo gak usah bilang-bilang Mama atau Mba Dewi, ya?!"

"Iya, Non, iya...."jawab Minah patuh sambil mulai membalur tubuh Diena dengan minyak zaitun. Gadis itu tengkurap di lantai beralas selimut.

Setelah kelar membaluri minyak zaitun sambil dipijat plus ber-scrubbing. Diena menyuruh MInah mencampuri air di bak mandi dengan susu bubuk.

Dah, lo boleh keluar. Gue mau berendam dulu, jadi jangan masuk kalau gak gue panggil" (Haid Pertama: 34$35)$.

Kalau pada umunya orang yang mempunyai pembantu seenaknya perintah ini dan itu, akan tetapi tidak terlalu kasar meminta bantuan kepada pembantunya. Seperti pada kutipan di atas, Diena hanya tahunya perintah pada hal pembantunya baru menghilangkan lelah dan letihnya karena telah memberesi pekerjaannya. Namun dasar Diena yang belum terlalu memahami kelelahan dan keletihan pembantunya, maka dia seenaknya memerintah. Tapi itu merupakan karakter yang tidak baik atau bisa dikatakan tidak mempunyai belas kasihan sesama manusia.

Mungkin penyebab kekasaran tuturan bahasa Diena terhadap pembantunya berkaitan dengan terlambatnya datang haidnya. Karena seumur Diena sudah pada mengalami hal tersebut.

"Teman-teman sekelasnya, perempuan sekelasnya, tiap tanggal-tanggal tertentu pasti ribut bicarain merk pembalut yang nyaman-lah, jenis-jenis 
ukuran pembalut mulai dari standard an maxi untuk darah haid yang tidak terlalu banyak, wing pembalut dengan sayap di kiri-kanan untuk diletakkan pada tepi kiri-kanan celana dalam agar darah haid tidak bleber, sampai long night yang dipakai untuk malam hari pas haid lagi banyak-banyaknya, terus pil-pil penghilang nyeri dan kram perut-lah, jerawat yang timbul tanda-tanda mau dapet, dan sebagainya" (Haid Pertama: 12-13)

Terlihat dari kutipan tersebut di atas, memang Diena sepertinya sedang kacau pikirannya, mencemburui teman-temannya yang setiap harinya memikirkan masalah haid. Sedangkan Diena pada umurnya mendekati 14 tahun itu belum juga merasakan haid.

Kejadian yang dialami oleh Diena, barulah diketahui oleh mamanya, karena mamanya selalu sibuk pergi ke kantornya.

"Tapi ngomong-ngomong kamu sudah haid belum, Dien? Maafin mama ya, mama sibuk sampai gak 'ngeh' gadis bungsunya sudah besar."

"Gak tahu!" Diena berbalik hendak meninggalkan Mama dan Mbak Dewi, betulkan apa yang ia duga. Dari masalah Minah sampai masalah pribadinya: haid, puber!’(Haid Pertama: 25).

Perbincangan Diena dengan mamanya pada kutipan di atas, sepertinya tidak berlangsung dengan baik, karena karakter Diena yang kurang bijak. Pada hal mamanya hanya ingin membantu Diena yang kelihatan cemberut terus pada pembantunya. Namun walaupun Diena tidak menjawab dengan terus terang dari pertanyaan mamanya, permasalahan diri Diena sepertinya sudah disadari dan diketahui oleh mamanya.

Karakter Diena sebenarnya tidak terlalu kasar atau jelek, hanya permasalahan keterlambatan datang haidnya membuat Diena jadi kasar, cemberut terus sama pembantunya dan keluarganya.

Diena juga adalah anak yang giat berusaha, contohnya saja Diena ke sekolah dan mencari solusi untuk memancing supaya keterlambatan haidnya dapat dipercepat. Salah satu usahanya adalah berkomunikasi terus dengan teman-temanya yang sudah mengalami haid itu, walaupun jawaban dari teman-temannya tidak terlalu mendukung permasalahan haidnya, tapi sedikit ilmu yang didapat oleh Diena.
Adapun perbincangan Diena yang berkaitan dengan masalah di atas adalah sebagai berikut:

"Lo semua udah baca buku biologi halaman tengah yang nerangin tentang sistem reproduksi pada wanita?"

"Ok, gue jelasin! Kita haid karena sel telur tidak dibuahi, proses detailnya..." Selama hari-hari ovulasi, hormonhormon mempertebal dinding uterus yang kemudian diperkaya oleh darah. Jadi bila sebuah telur yang tebuahi... you know-lah terbuahi?"

"Jadi bila sebuah telur yang terbuahi tiba di uterus, dinding itu sudah siap untuk menerimanya. Dan kalo gak dibuahi atau tidak berhubungan seks, dinding yang menebal itu tidak diperlukan lagi akan terbuang menjadi darah haid. Maka cewek yang gak haid ... berarti mandul, kan?"

Diena menggidik mengingat ucapanucapan Ayu" (Haid Pertama: 13-14).

Dari kutipan di atas dapatlah digambarkan bahwa Diena memiliki sifat yang giat berusaha dalam menghadapi pendapat orang lain.

Selain sifat yang menggambarkan pada kutipan-kutipan terdahulu, Diena menurut kutipan di bawah ini, memiliki sifat penakut dan pemalu, namun sedikit berani.

"udahlahhh ...itu di bahas nanti aja, gue ada pertanyaan serius bangat nih." Akhirnya Diena nekat memutuskan untuk bertanya setela ia pikir, toh Cecilia tidak malu-malu menceritakan ciuman bibir sama cowoknya. Lagi pula mereka kan, sama-sama cewek. Cecilia pasti pernah merasakan berdenyut seperti yang Diena rasakan.

"Ada apaan sih?"

"Nggg...Cil, kenapa sih gue kalau denger cerita ciuman punya gue bberdenyut?"

"Maksud lo?" Cecilia memperjelas.

"Itu... aduh, gimana ngejelasinnya ya?" "Begini, Cil...berdenyut seperti ingin pipis. Pokoknya rasa itu menggelisahkan,"

Tiba-tiba tawa Cecilia meledak, "Lo bego banget sih, Dien. Namanya lo terangsang, tahu!" 
"T-terangsang?" suara Diena hampir tak terdengar, namun jelas wajahnya terkejut" (Haid Pertama: 18-19).

Keseluruhan kutipan yang dipandang dari segi perbincangan Diena dengan teman bicaranya, terlihat suatu sifat yang sedikit keras, namun di balik sifatnya yang keras itu, Diena juga merupakan sosok tokoh utama yang digambarkan oleh pengarang sebagai tokoh yang rajin atau giat berusaha dan pemalu.

b. Gambaran karakter didasarkan pada reaksi pelaku terhadap peristiwa tertentu.

Dalam penggambaran karakter pelaku pada cerita dapat juga dilakukan dengan salah satu cara yakni dengan melihat dan mangamati bentuk reaksi pelaku terhadap peristiwa yang dihadapinya. Untuk lebih jelasnya, dapat dilihat kutipan berikut:

"Lo kenapa sih?" suara Diena sedikit kasar, mendadak ia kehilagan mood bicara dengan temannya itu. Kenapa sih, ia harus menderita perbedaan dengan teman-temannya?

Kapan datangnya sang haid? Hampir tiap bulan ia berharap-harap cemas. Kalau-kalau dirinya lesu, marah-marah, atau malas-malas, dan berjerawat, sebagai tanda-tanda haid seperti cerita teman-temanya" (Haid Pertama: 11).

Kutipan diatas menggambarkan reaksi Diena terhadap permasalahn yang sedang dihadapi oleh Diena sendiri. Temannya menyinggung perbedaan pendiriannya dari penderitaan yang dialami oleh Diena dengan teman-temannya yang lain. Namun dalam hal tersebut, Diena sedikit menaruh perasaan tersinggung terhadap temannya itu, karena telah membicarakan permasalahan keterlambatan haid yang dialami langsung oleh Diena.

Permasalahan ketersinggungan Diena kepada lawan bicaranya tidak pernah pudar dalam hatinya. Ini berkaitan dengan orang-orang disekitarnya yang selalu menyindir dan membicarakan keterlambatan haidnya, bahkan Diena dituduh oleh teman sebagai cewek yang tidak normal, kuper dan bego.

Adapun kutipannya sebagai berikut:

"Sumpah, Diena jadi bete habis! Haid yang tak kunjung-kunjung nongol, cowok-cowok yang cuma ia sukai diamdiam, sindiran teman-temannya, dan cerita-cerita mereka soal pacaran, terus ucapan Cecilia atas ceritanya mengenai onani, kayaknya ia menjadi cewek yang super gak normal, kuper dan bego" (Haid Pertama: 24).

Pada kutipan lain menyebutkan, bahwa Diena memang betul sedang pusing dan sedih memikirkan keterlambatan haid sebagai tanda perempuan normal. Berbagai pengalaman yang telah dialami dan diceritakan oleh temantemannya, namun apalah daya Diena hanya bisa memandang tubuhnya yang kurus dan tiada sexi.

"Dengan kecewa dan sedih, ia pandangi cup BH yang terkesan kosong menempel di dada karena payudaranya tidak mengisi penuh cup itu. Pada hal sudah ukuran terkecil, dan ia pikir payudaranya tidak kecil-kecil amat. Ada-lah tonjolannya, tidak rata. Tapi rupanya, bukan ukuran standar normal. Buktinya pakai BH terkecil pun tidak bisa" (Haid Pertama: 28).

Jangankan memakai BH sebagai penanda perempuan yang sexi sedangkan miniset saja masih rata dibagian dadanya, atau karena Diena betul-betul belum mendapatkan haid pertama.

Kejadian yang terjadi pada kutipan dan penjelasan di atas, menunjukan sifat sedikit kecewa dan gampang sedih, atau dalam hal ini sifat tidak sehat dalam menghadapi permasalahan.

Salah satu bentuk yang diberikan oleh temannya untuk mengatasi ketidak sabarannya dalam permasalahan haid yang tidak kunjung datang adalah temannya mencoba menawarkan kepada Diena untuk segera berpacaran sebagai pemancing hormon-hormon kewanitaannya.

"Apa ia pacaran saja, ya? Biar bisa ciuman, pelukan, dan terangsang untuk merangsang hormonnya. Kayaknya kata-kata Cecilia betul, sebab ia pernah membaca kalau seorang cewek telat haid atau dapat haid di usia yang cukup tua, perlu diberi obat atau suntikan hormon agar normal. Walau ia belum pernah baca teori yang menyatakan pacaran mempercepat haid. Pokoknya ia harus pacaran, tapi sekali lagi, dengan siapa gitu loh?" (Haid Pertama: 29).

Bila dilihat dari kutipan di atas, teori yang dikatakan oleh temannya mengenai minum obat dan suntikan hormon bisa dikatakan hal yang dapat dilakukan oleh Diena, Akan tetapi kalau 
disuruh pacaran, ciuman, pelukan, dan terangsang merupakan perbuatan yang jijik bagi Diena.

Reaksi Diena dalam hal di atas, terlihat suatu sifat yang penuh ketelitian dan sedikit keraguan. Walaupun Diena sangat menghargai pendapat dan usulan dari temannya itu.

$$
\text { Pada kutipan selanjutnya }
$$

menggambarkan suasana setelah mengalami pacaran. Berarti Diena sudah melaksanakan usulan dari temannya untuk mencoba dengan jalan pacaran.

Adapun kutipannya sebagai berikut:

"E-gue minta maaf tor,... .

Toro menatap Diena heran.

"Gue sebenarnya ... gak pernah feel sama lo, ciuman di bibir itu. Cuma karena gue penasaran. Makanya gue SMS begitu sama lo seminggu yang lalu ..."

Toro tercengang.

'Jadi jangan paksa gue untuk jadi pacar lo ..."

Toro terhempas.

"Sekarang gue mau pulang ..." Diena hendak berbalik. (haid pertama: 78).

Dari kalimat atau bahasa yang tertera pada kutipan tersebut, Diena sedang menghadapi permasalahan serius dengan pacarnya Toro. Bahkan Diena sudah memberikan ciuman terhadap pacarnya, namun Diena tidak pernah merasakan kegairahan untuk memancing hormon-hormonnya.

"Tidak ada rasa apa-apa selain takut dan gamang katanya nikmat, kok nikmatan saat mimpi ciuman sama Duran meski cuma pipi?

Cuma sesudahnya ia merasakan kepalanya pening dan tubuhnya lemas" (Haid Pertama: 60).

Jadi, bentuk reaksi pelaku dalam adegan tersebut hanya sebagai pelampiasan dari bentuk penasarannya, serta sebagai usahanya untuk memancing hormon kewanitaannya.

Dilahat dari kutipan-kutipan di atas menampakkan sifat Diena dalam reaksi menghadapi pacaran. Sebagai reaksi yang tidak mempunyai pendirian tetap. Permasalahannya, karena Diena masih bergelimang dengan dunia kebebasan dalam melangkahkan kakinya.

Sudah banyaklah peristiwa-peristiwa yang dialami oleh Diena dalam menunggu kedatangan haidnya yang tiada pasti.
Pada suatu saat Diena mengikuti sebuah acara tepat malam tanggal kelahirannya, disitulah kejadian yang bersejarah bagi diri Diena.

"Diena menatap dirinya di depan cermin, tapi perutnya semakin melilit dan mual sekali, cepat ia masuk ke bilik toilet. Apa ia akan buang air besar, tapi kok melilitnya aneh, bukan di perut tapi di bawah pusar? Keringat dingin membasahi seluruh kostum yang ia kenakan. Pelan-pelan Diena jongkok setelah dibuka celana dalamnya, tapi lima menit berlalu tak juga keluar. Akhirnya ia memutuskan untuk kembali ke acara, namun ketika celana dalam akan dikenakan ...

Hah? Mata Diena melotot. Darah! Darah itu tercecer di celana dalamnya sedikit saja, tidak banyak. Tuhan, tolong! Sempoyongan Diena keluar dari bilik toilet" (Haid Pertama: 101-102).

Dari kejadian dalam kutipan itu memberikan reaksi dan perubahan prilaku Diena sejenak. Sedikit takut, karena kaget baru pertama kali melihat darah yang tercecer dalam celana dalamnya.

Oleh karena datangnya haid tersebut, perasaan nan bahagia yang dirasakannya tiada tara.

“...sakit hati, berdebar, namun bahagia ia sudah menjadi cewek sempurna. Jadi apakah ini kado ulangtahunnya dari tuhan?" (Haid Pertama: 104).

\section{c. Penggambaran karakter berdasarkan kebiasaan atau kegemarannya.}

Seperti yang dikemukakan oleh Ichsan (2004: 46) bahwa penggambaran karakter lewat kebiasaan dan kegemaran ini biasa dikaitkan dengan hobi atau kesenangannya itu, dapatlah kita ketahui tentang karakter pelaku tersebut.

Jadi penggambaran karakter yang dipandang pada diri Diena dapat dilakukan melalui kebiasaan dan kegemarannya terhadap sesuatu yang menjadi hobinya.

Seperti kutipan di bawah ini:

"Besok aja deh pulang sekolah kita ke

Plaza Merah Putih, kabarnya kita pulang setengah hari karena guru-guru rapat" (Haid Pertama: 10).

Dilihat dari kutipan di atas terlihat kebiasaan Diena yang selalu ke Plaza Merah 
Putih. Bisa dikatakan bahwa Diena mempunyai karakter dan sifat yang selalu ingin mencari hiburan yaitu jalan-jalan ketempat keramaian, seperti tempat perbelanjaan yang elit-elit atau bermegah-megahan.

Karakter yang dimiliki Diena layaknya anak-anak pada umumnya atau sederajatnya, memang memiliki karakter yang selalu mencari hiburan, ingin selalu bermain dengan temantemannya.

Contoh kutipan selanjutnya adalah sebagai berikut:

"Rencana ke Plaza Merah Putih dibatalkan, jadi ke Batavia Town Square, tempat tongkrongan yang asyik selain Plaza Merah Putih, hingga mereka mampir ke café" (Haid Pertama: 17).

Kebiasaan dan kegemaran Diena adalah sesuatu yang wajar-wajar saja, karena kebiasaan dan kegemarannya hampir semua manusia mempunyai dan berkeinginan seperti yang dilakukan oleh Diena, yaitu berjalan-jalan ketempat belanja yang asyik dan menggairahkan hati, bergaya dan bersahabat.

Selain dari kebiasaan tersebut, Diena juga terbawa pada sifat yang searah dengan keadaan dan suasana pada tempat yang sering dikunjunginya. Melihat barang ini dan itu, cantik, milihat orang-orang yang bergaya dan berpakaian yang bagus sehingga menjadi bahan yang dapat dicontohi oleh Diena. Akhirnya Diena menjadikan sifat dan kebiasaannya pada hal-hal tersebut, seperti kutipan di bawah ini:

"Sekali lagi Diena bercermin, ia tersenyum puas melihat dirinya dibalut dress selutut dengan tali, tunggal warna krem, tas model clutch atau tas tangan tanpa tali, bentuknya kecil dengan panjang $20 \mathrm{~cm}$ ditaburi garlic warna pink hasil pinjaman dari Mba Dewi dengan alasan untuk ke ultah teman, untuk sepatu ia pilih model knit shoes warna senada dress. Make up-nya tipis seperti biasa, dan untuk sentuhan terakhir ia semprotkan sebuah parfum khusus wanita dalam perpaduan aroma bunga mawar dan lilac yang dikeluarkan stella McCartney" (Haid Pertama: 50).
Diena mempunyai sifat dan kebiasaan bersolek, menghiasi diri supaya tampil beda di depan orang-orang di sekitarnya.

"Aku cantik, cukup cantik, bisik Diena meyakinkan dirinya. Lantas dimasukkan kembali cermin kecilnya ke clutch yang ia genggam erat" (Haid Pertama: 52).

Dari kesemua kutipan tersebut, Diena berkarakter pada kebiasaan dan kegemaran yang sama dan biasa dilakukan oleh para gadis-gadis lain. Menghiasi diri, bersolek, serta berpenampilan yang selalu tampil beda.

Jadi, karakter Diena dilihat dari persoalan kebiasaan dan kegemaran, lebih cenderung pada sifat yang bernuansa hiburan dan selalu ingin tampil beda dari teman-temannya. Namun tidak bisa dipungkiri hal tersebut adalah wajar-wajar saja karena hal tersebuat semua kegiatan anak-anak baru gede. Yaitu masih berpikiran sesaat atau belum bisa berpikir ke arah yang akan datang.

\section{KESIMPULAN DAN SARAN}

\section{A. Kesimpulan}

Adapun kesimpulan dalam penelitian ini sebagai berikut:

1. Faktor sikap

a. Penggambaran karakter pelaku utama melalui bentuk tubuh pelaku.

Gambaran karakter Diena melalui gambaran bentuk tubuhnya, berkarakter suka berpenampilan menarik dan bisa dikatakan tomboy, karena penampilan seperti ini merupakan penampilan dan sisfat anak-anak sederajatnya, dan dapat dikatakan sebagai sifat yang biasa dimiliki oleh anak-anak pada umurnya.

b. Penggambaran pelaku utama melalui perbincangan dengan pelaku lain

Penggambaran karakter dari segi perbincangan dengan pelaku lain dan di antara pelaku lain merupakan usaha untuk menggambarkan karakter yang dimiliki oleh pelaku utama.

Setelah diamati dengan sebaik-baiknya perbincangan pelaku utama dengan pelaku lain dan desas-desus antara pelaku lain, terdapat suatu karakter yang dimunculkan oleh pengarang terhadap Diena adalah karakter atau sifat yang terkadang kasar dan juga giat berusaha dalam menghadapi persoalan intim yaitu masalah haidnya yang belum juga 
datang, dari persoalan terlambat datang haidnya, maka Diena dapat digambarkan sebagai tokoh yang mudah cepat marah serta giat berusaha.

2. Penggambaran karakter pelaku utama didasarkan pada reaksi pelaku terhadap peristiwa tertentu.

Perilaku dan sikap Diena dalam menghadapi segala peristiwah yang menimpa dirinya, tidak mempunyai pendirian yang tetap, yang akhirnya membawa sifat Diena ke arah sifat yang selalu tersinggung. Namun ada juga sifatnya sabar edan tabah, karena berkaitan dengan berbagai macam usahanya untuk menunggu dan menantikan kedatangan haidnya yang belum juga kunjung datang. Sehingga dari kesabaran dan ketabahannya, akhirnya mendapatkan atau datang juga haidnya dalam umurnya.......ketika Diena sedang mengikuti sebuah acara perpisahan kakak-kakak kelasnya.

Peristiwa datang haidnya, keadaan Diena begitu tidak menentu karena peristiwa tersebut datang tepat di malam acara perpisahan kakak-kakak kelasnya yang apada saat itu Diena termasuk pemain dan penghibur dalam acara itu.

3. Penggambaran karakter berdasarkan kebiasaan dan kegemarannya.

Bentuk karakter yang digambarkan berdasarkan pada kebiasaan kegemarannya, ditemukan suatu karakter anak-anak yang mempunyai pola pikir sesaat. Contoh, Diena mempunyai kebiasaan dan gemar berrefresing atau jalan-jalan ke mall-mall (Plaza Merah Putih) dan tempat keramaian lainnya. Jadi bisa dikatakan bahwa Diena seperti layaknya anak-anak perempuan yang lain mempunyai kebiasaan dan hobi mencari hiburan dan kesenangan sendiri. Dalam arti kasarnya adalah yang penting senang bagi dirinya.

Dari kesemua penggambaran karakter pada tokoh Diena, terlihat karakter yang tidak menentu. Ketidaktentuannya sifat Diena tersebut karena:

1. Faktor keterlambatan datang haidnya adalah faktor utama yang menyubah keadaan dan karakternya.

2. Faktor umurnya yang masih muda dan tergolong masih dalam sifat bebas atau belum bisa berpikiran yang tepat. Hal ini bukan saja yang dimiliki oleh Diena, tetapi hampir semua anak-anak gadis yang kisaran umurnya sama dengan
Diena, mengalami atau memiliki karakter dan sifat yang sama.

\section{B. Saran}

Berdasarkan hasil analisis ini, terdapat beberapa saran dan usulannya sebagai berikut:

1. Kepada mahasiswa Jurusan Pendidikan Bahasa dan Sastra Indonesia agar dapat mengembangkan penelitian sastra dengan sebaik-baiknya, yang khususnya dalam menganalisis faktor nilai karakteristik yang terdapat dalam sebuah karya sastra atau novel.

2. Kepada peneliti yang akan datang dan yang mengambil novel Haid Pertama karya Enny M. sebagai bahan penelitiannya, diharapkan dapat meneliti, mengkaji, dan mengambil hal-hal lain yang sangat penting dan perjalanan kisah ceritanya dijadikann sebagai perwujudan dalam kehidupan sehari-hari.

3. Diharapkan kepada pembaca agar memperoleh manfaat dan hidayahnya dari hasil penelitian ini demi menambah khasanah ilmu pengetahuan serta pengalaman.

4. Diharapkan kepada pendidik supaya memberikan sisi posotif dari kisah yang diceritakan untuk anak didiknya agar dapat menghindari hal-hal yang negatif dalam kehidupan sehari-hari.

\section{DAFTAR PUSTAKA}

Aminuddin. 1987. Pengantar Apresiasi Karya Sastra. Malang Sinar Baru Al Gasindo.

Aminuddin. 2002. Pengantar Karya Apresiasi Karya Sastra. Bandung: Sinar Baru.

Hardjana. 1981. Kritik Sastra Indonesia Modern. Jakarta: Gramedia Utama.

Hartono. 2005. Kamus Besar Bahasa Indonesia. Surabaya: Mitra Pelajar

Hasan. 1990. Karateristik Penelitian Kualitatif dalam Amiruddin (Ed). Pengembangan Penelitian dalam Bidang Bahasa dan Sastra. Malang: HISKI Komisariat Malang dan YA3.

Ichsan, Muhammad. 2004. Analisis Karakteristik Bu Suci dalam Novel Pertemuan Dua Hati karya Nh. Dini. Skripsi. Makassar: FKIP Unismuh.

Jassin. H.B. 1985. Kesusastraan Indonesia Modern dalam Kritik Essay. Jakarta: Gramedia.

Keraf. Gorys. 1989. Argumentasi dan Narasi. Jakarta: Gramedia. 
Muhsin, M. Arief. (2016). The Developtment of Creative Writing Model on Short Story Based Siri'Na Pacce at the XI Class Senior High Schools in Makassar. Journal of Educational and Social Research, 6(1), 52.

Muhsin, Muh. Arief. 2016 . The Effectiveness of Positive Feedback in Teaching Speaking Skill. Lingua Cultura, 10(1), 25-30. http://dx.doi.org/10.21512/lc.v10i1.873

Nurbaya. 2002. Analisis karakter Tokoh Wanita dalam Novel Masyato Karya Ajib Rosidi Skripsi. Makassar: FKIP Unismuh.

Nurgiantoro, Burhan. 1998. Teori Pengkajian Fiksi. Yogyakarta: Gajah Muda University Press.

Pradopo, Djoko. 1979. Kritik Sastra Indonesia Modern. Yogyakarta: Gramedia.

Purwanto, Ngalim. 1990. Psikologi Pendidikan. Jakarta: Remaja Rosdakarya.

Sadjiman, Panji. 1990. Kamus Istilah Sastra. Jakarta: Universitas Indonesia.

Saharuddin. 1995. Analisis Unsur Intrinsik pada Sebuah Kapal Karya Nh. Dini. Skripsi. Makassar FKIP Unismuh.

Sudjiman, Panuti. 1984. Kamus Istilah Sastra. Jakarta: Gramedia.

Suharianto. 1982. Dasar-dasar Teori Sastra. Surakarta: Widya Duta.

Sumardjo. Jakob. 1984. Memahami Kesusatraan. Bandung: Almuni

Surahmat, 1985. Pengantar Penelitian Ilmu Dasar, Metode dan Teknik. Bandung: Tarsito

Suryabrata,Sumardi. 1990. Psikologi Kepribadian. Jakarta: Makassar.

Tarigan, H. G. 1985. Prinsip Dasar Sastra. Bandung: Angkasa

Tarigan, H. G. 1998. Prinsip-prinsip Dasar Sastra. Bandung: Angkasa

Wirawan. 1992. Psikologi Lingkungan. Jakarta: PT Gramedia Widyasarana Indonesia. 